\title{
Snow-accumulation distribution in the interior of the Lambert Glacier basin, Antarctica
}

\author{
Martin Higham, Mike Craven, Andrew Ruddell, Ian Allison \\ Antarctic CRC and Australian Antarctic Division, GPO Box 252-80, Hobart, Tasmania 7001, Australia
}

\begin{abstract}
A prime input variable to uncoupled ice-sheet models, or for estimating the mass budget of present-day ice sheets, is the distribution of net surface mass balance. In most cases this is extrapolated from relatively few direct measurements over a limited time period, and parameterised in terms of continentality, surface elevation and other broad-scale indicators. Between 1989 and 1995 a series of oversnow traverses around the interior of the Lambert Glacier basin gathered a comprehensive set of data on snow accumulation and surface properties, surface climatology, ice-sheet velocities, elevations and thicknesses. Above the $2000 \mathrm{~m}$ level accumulation averages were found to be $76 \mathrm{~kg} \mathrm{~m}^{-2} \mathrm{a}^{-1}$ $(\sigma=74)$, much lower than at similar elevations in Wilkes Land. The traverse route contains three distinct accumulation regimes: a relatively high accumulation zone along the western side despite higher average elevations, a very low accumulation zone in the south due to the effect of increased continentality and an eastern sector that exhibits a rain-shadow effect in predominantly easterly wind fields. Inter-annual variability is high, with 1993 a colder year, recording only half the longer term average accumulation over the portion of the route that was measured.
\end{abstract}

\section{INTRODUCTION}

The Lambert Glacier basin system occupies almost $1000000 \mathrm{~km}^{2}$ between eastern Kemp Land and western Princess Elizabeth Land from $55^{\circ}-80^{\circ} \mathrm{E}$ draining around one-eighth of the East Antarctic ice sheet. The Lambert Amery Regional Glaciological Experiment (LARGE), conducted for the Antarctic Division by the Australian National Antarctic Research Expeditions (ANARE), operated a series of oversnow traverses from 1989 to 1995 in order to investigate the dynamics and mass budget of the basin. The mass budget has been estimated in the past from extrapolation of isolated measurements (Allison, 1979) and interpretation of satellite imagery (McIntyre, 1985), offering alternative descriptions of the current state of balance.

Initial results from LARGE confirmed indications (Giovinetto and Bull, 1987) that the western coastal sector of the basin receives low accumulation $\left(<150 \mathrm{~kg} \mathrm{~m}^{2} \mathrm{a}^{-1}\right)$ with variability of about $50 \%$ independent of elevation or continentality (Goodwin and others, 1994). Results for the entire route demonstrate some elevation and continentality effects over the western and southern extremities, continued high variability indicative of surface snow redistributed by a strong wind regime, and lower accumulation rates at equivalent altitudes for the eastern sector of the basin.

The traverse program established a series of ice-movement stations, for GPS satellite determination of ice-sheet velocities, at $30 \mathrm{~km}$ intervals along more than $2000 \mathrm{~km}$ of track (Fig. 1). Double-tagged bamboo canes were spaced every $2 \mathrm{~km}$ along the entire route to aid navigation and facilitate measurement of spatial and temporal (western sector) variability in annual snow accumulation. At each station $10 \mathrm{~m}$ firn temperatures were recorded and shallow $2 \mathrm{~m}$ cores were drilled for measurements of density, strati-

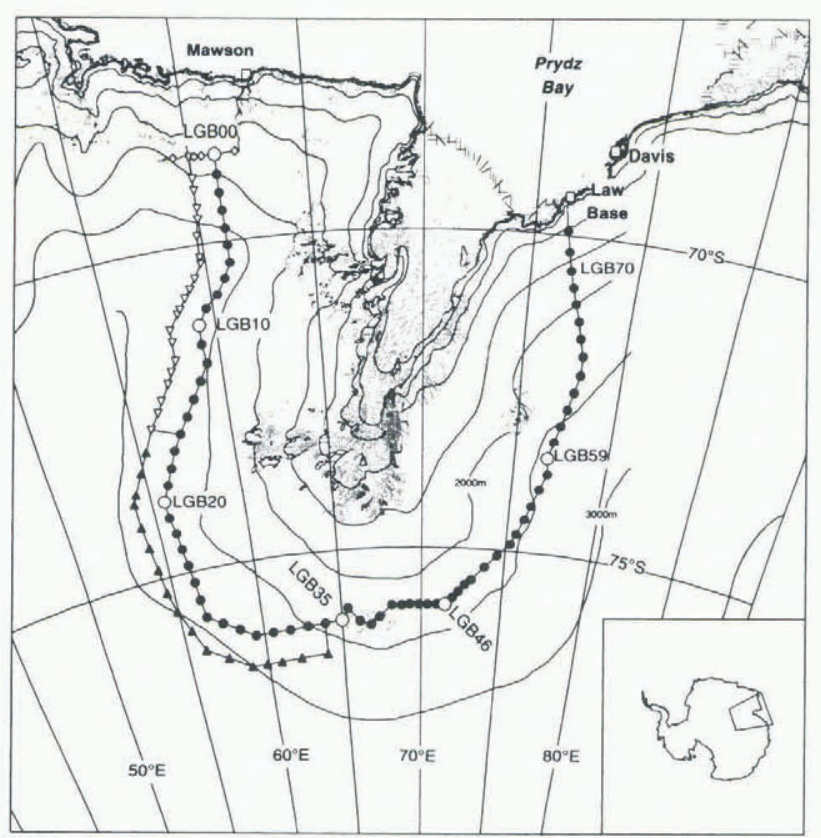

Fig. 1. Map of the Lamberl Glacier basin (Antarctic location inset) and LARGE operational area 1989-95, showing AWS (open circles), main traverse route and stations (dark circles), offset lines (triangles) and short western route (diamonds).

graphy and isotope analysis studies of climatological aspects of the precipitation. At seven selected stations, cane farms consisting of 20-25 canes at $200 \mathrm{~m}$ intervals in square or crossed arrays (with axes parallel and perpendicular to prevailing winds) were established in order to determine accumulation dependence on small-scale topography and localsurface microrelief. All but one (LGB68) coincide with 
$L e g$

LGB00-LGB16

L.GB16-LGB35

LGB35 LGB72

\section{Distance}

Periods with measurements aiailable

\begin{tabular}{l|cccc}
$504 \mathrm{~km}$ & $1989-90$ to $1990-91$ & $1990-91$ to $1992-93$ & 199293 to 199394 & $1993-94$ to $1994-95$ \\
$576 \mathrm{~km}$ & & $1990-91$ to $1993-94$ & 199394 to 199495 \\
$934 \mathrm{~km}$ & & & $93-94$ to $94-95$
\end{tabular}

automatic weather stations (AWS), spaced at roughly $300 \mathrm{~km}$ intervals around the basin, which routinely relayed remotely sampled meteorological data. Shallow cores were drilled to depths of $15-60 \mathrm{~m}$ at 15 selected sites around the basin for stratigraphic studies of annual layers and analysis of grain-sizes within the firn.

The route follows a nearly constant elevation along the $2500 \mathrm{~m}$ contour where surface slopes and wind speeds are typical of the katabatic zone. The low surface mass balance gives the near-surface firn different characteristics from those found for a given elevation in many other parts of East Antarctica (Goodwin and others, 1994). An understanding of the dependence of firn properties on accumulation rates can be used in the interpretation of remotely sensed data covering the entire drainage basin.

\section{SURFAGE MASS BALANCE}

\section{Measurement techniques}

Measurements of surface mass balance were made on 989 bamboo canes spaced at $2 \mathrm{~km}$ intervals, with accuracy estimated to be $\pm 20 \mathrm{~mm}$ absolute, over $2014 \mathrm{~km}$ of traverse route at surface elevations up to $3000 \mathrm{~m}$ (Table 1). For each period, annual mass-balance values have been calculated assuming no seasonal variability. Surface net-accumulation distributions derived from atmospheric-moisture fluxes show relatively little systematic variation during the year for inland regions above $1500 \mathrm{~m}$ (Budd and others, 1995).
Measurements of surface snow density along the traverse route were obtained from an average value for the upper metre of a shallow core collected every $2 \mathrm{~km}$. This includes the windpacked surface plus snow undergoing firnification with associated density changes. Values range from $480 \mathrm{~kg} \mathrm{~m}^{-3}$ under the strong katabatic effect on the nearcoastal slopes, to a low of $360 \mathrm{~kg} \mathrm{~m}^{-3}$ along the southern part of the route due to shallow depth hoar development, with an overall average of $408 \mathrm{~kg} \mathrm{~m}^{3}$.

\section{Accumulation regimes}

The spatial variation of snow accumulation around the basin is plotted with ice surface elevation against distance in Figure 2. The broadscale topography is undulating on a wavelength of approximately $350 \mathrm{~km}$ over the western half of the basin, changing in character to around $150 \mathrm{~km}$ wavelength across the southeastern portion of the route up to LGB61, from where the surface elevation begins a steady decline toward the coast. The accumulation data have been smoothed over $30 \mathrm{~km}$ (15 canes) using an unweighted running mean and have been converted to mass using near-surface density measurements. Smoothing removes high frequency fluctuations that are due to local effects, but the consequences of large-scale features remain. Standard deviations, exhibiting strong anti-correlation with accumulation, have been determined for each $30 \mathrm{~km}$ interval and are shown divided by the mean as coefficients of variation in Figure 2.

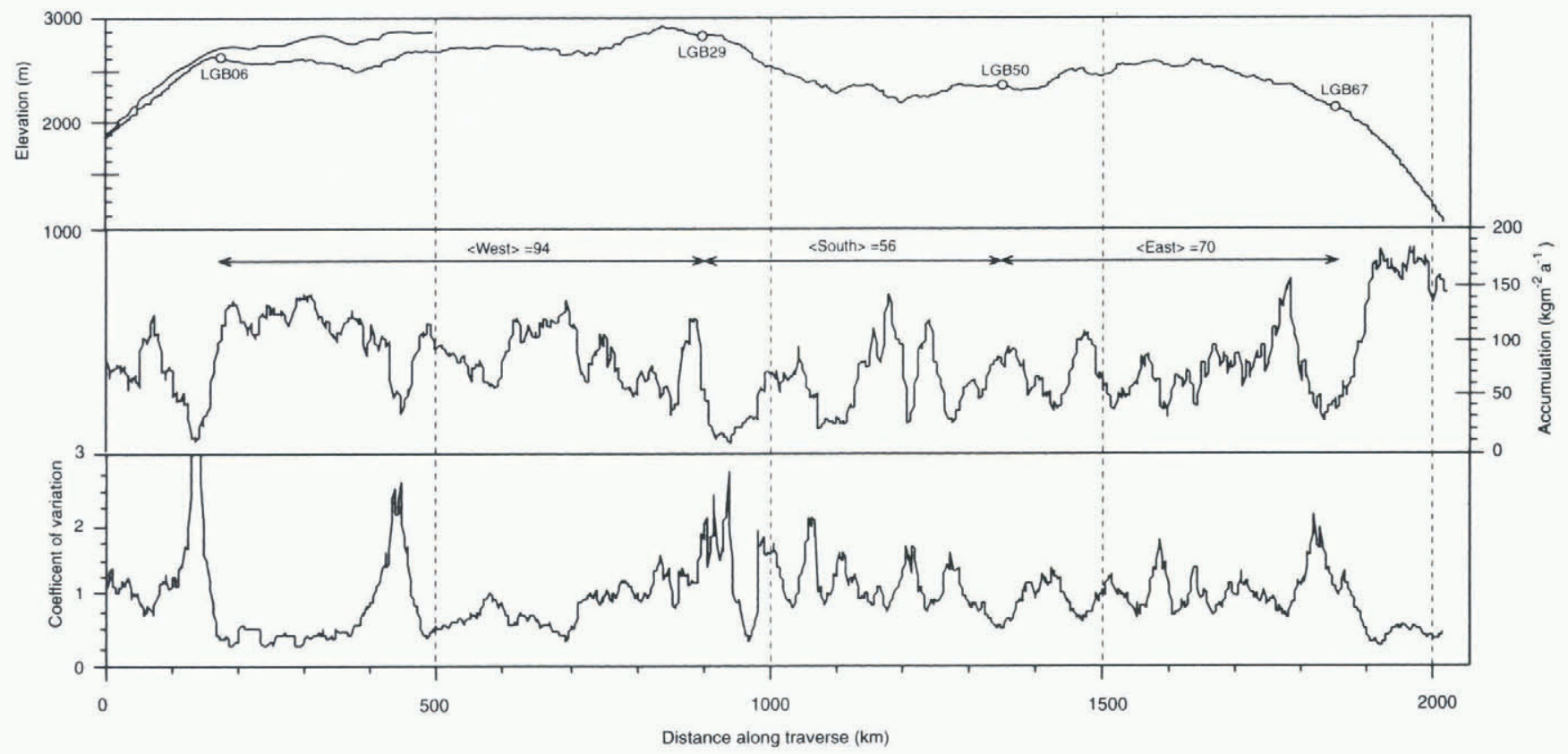

Fig. 2. Surface elevations ( $\mathrm{msl}$ ) along the traverse route (top), including the first $500 \mathrm{~km}$ of western offset line, plotted against 1994 accumulation figures (middle) and the coefficient of variation (bottom). The large peak around $130 \mathrm{~km}$ has a value of 6.4, due to the very low accumulation near the break in coastal slope. 
The basin can be divided into three main accumulation regimes: the western sector from LGB06 to LGB29 with an annual 1994 mean accumulation of $94 \mathrm{~kg} \mathrm{~m}^{-2} \mathrm{a}^{-1}(\sigma=74)$; the southern sector from LGB29 to LGB50, $56 \mathrm{~kg} \mathrm{~m}^{-2} \mathrm{a}^{-1}$ $(\sigma=72)$; and the eastern sector from LGB50 to LGB67, $70 \mathrm{~kg} \mathrm{~m}^{2} \mathrm{a}^{-1}(\sigma=71)$. The standard deviations have similar absolute values, with magnitudes close to the mean within each zone, indicating that they represent the average surface microrelief contribution to variability. Stratigraphic analysis of shallow firn-core samples $(15-60 \mathrm{~m})$ has failed to yield reliable accumulation-rate time series due to masking of the annual layering by aeolian processes driving surface microrelief features of similar magnitude and the occurrence of depth-hoar metamorphism, tending to further confuse identification of strata.

The low accumulation figure across the southern portion of the route is a reflection of continentality superimposed on a small elevation trend, whilst lower accumulation on the eastern sector compared to that at equivalent altitude on the western sector is a function of the surface-wind regime and ice-sheet gradients across the basin. This rain-shadow effect is consistent with observations of higher accumulation rates on windward compared to leeward slopes in Wilkes Land for elevations around $2000 \mathrm{~m}$ (Goodwin, 1990). Scattergrams of accumulation vs elevation show a small dependence superimposed on large variability for the western and southern sectors, with no evidence for dependence on the eastern side (Fig. 4). This indicates an eastern sector where accumulation is controlled by topographic features with the amount of enhancement in the valleys dependent on localised gradients rather than absolute elevation.

Repeat measurements from LGB00 to LGB16 give an indication of the temporal variability of the annual net-surface balance for the region (Fig. 3). Of particular interest are the low accumulation record for 1993 and the high for 1990.

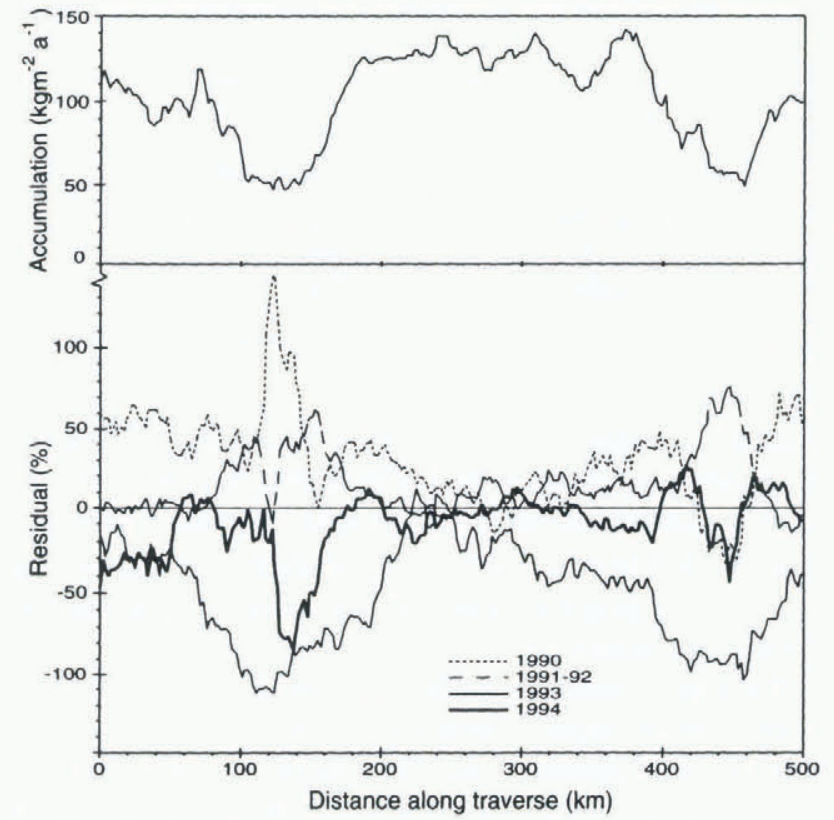

Fig. 3. Inter-annual variability from LGBOO to LGB16 shown in terms of percentage residuals for individual periods (bottom) from the 1990-945 year mean (top).

1993 was the second coldest year at Mawson since station records began in 1955 (a mean annual temperature of $-13^{\circ} \mathrm{C}$ compared to the long term 39 year mean of $-11.2^{\circ} \mathrm{C}$ ). Average accumulation over the $504 \mathrm{~km}$ from LGB00 to LGB16 was $56 \mathrm{~kg} \mathrm{~m}^{-2} \mathrm{a}^{-1}(\sigma=76)$, half the 5 year average for the area. For 1990 the average was $131 \mathrm{~kg} \mathrm{~m}^{-2} \mathrm{a}^{-1}$ $(\sigma=104)$ whilst the mean temperature was close to average at $-10.8^{\circ} \mathrm{C}$, the larger standard deviation perhaps indicative of increased microrelief features, particularly on the break in slope around the ridge line near LGB05 and a smaller gradient change on the southern extremity of the valley run-

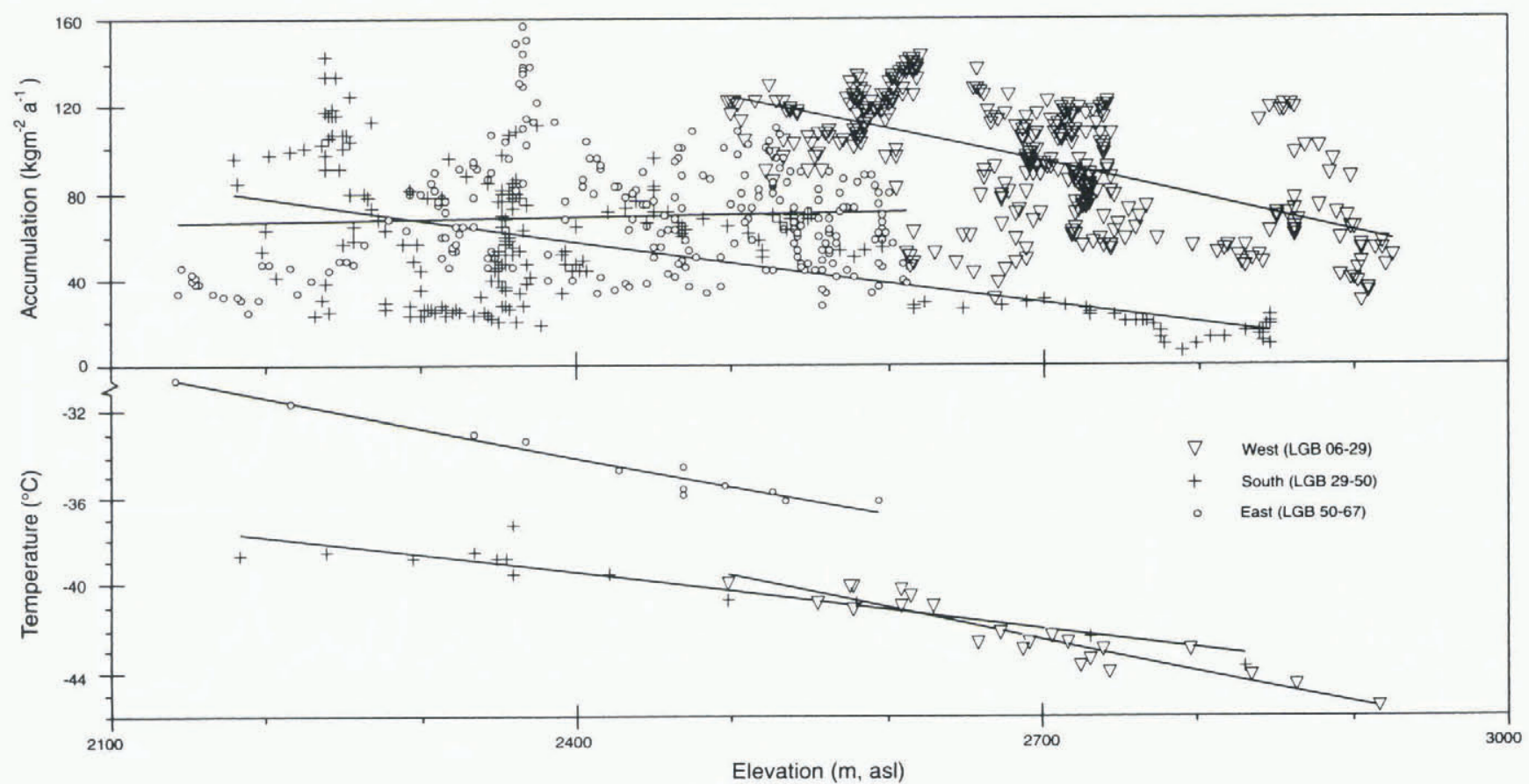

Fig. 4. Elevation scattergrams for the three accumulation regimes in the Lambert basin (top). The eastern sector (circles) shows no dependence on elevation. The $10 \mathrm{~m}$ firn temperatures vs elevation plots (bottom) depict lapse rates that are slightly superadiabatic for the eastern and western (triangles) sectors. 
ning across the route between LGB10 to LGB14. April-May temperatures were, however, some $3-4^{\circ} \mathrm{C}$ above the longterm averages, indicating possible intrusion of moistureladen air during the early phase of sea-ice formation, resulting in heavier snowfall through this period. This could indicate possible seasonality in the accumulation pattern, which has, however, not been included in the calculations for balance years. The high variability emphasises the need for accumulation measurements to be carricd out over periods of at least 3-4 years. The 1994 accumulation record (Mawson mean temperature of $-11.5^{\circ} \mathrm{C}$ ) was consistent with the 5 year average $\left(93 \mathrm{~kg} \mathrm{~m}^{2} \mathrm{a}^{-1}(\sigma=74)\right.$ vs $101 \mathrm{~kg} \mathrm{~m}^{-2} \mathrm{a}^{-1}$ $(\sigma=81)$, most of the discrepancy accounted for over the first $150 \mathrm{~km}$ of steep coastal slope) increasing confidence in the figures recorded for one season only over the eastern sector.

Cane farms were established at approximately $300 \mathrm{~km}$ intervals along the route to facilitate investigation of smallscale spatial variability. Even for very low accumulation (LGB35, 1994) the standard deviation remains around $30 \mathrm{~kg} \mathrm{~m}^{-2} \mathrm{a}^{-1}$, indicating a possible lower limit to average local microrelief size (Table 2). This corresponds to about half the standard deviation found over the entire traverse route $\left(70 \mathrm{~kg} \mathrm{~m}^{-2} \mathrm{a}^{-1}\right)$.

Cane-farm averages and track canes compare favourably. For example, LGB10, where the cane-farm average was $122 \mathrm{~kg} \mathrm{~m}^{-2} \mathrm{a}^{-1}(\sigma=40)$, the station cane over the same 5 year period (1990-94) recorded $145 \mathrm{~kg} \mathrm{~m}^{-2} \mathrm{a}^{-1}$, while the $30 \mathrm{~km}$ (15 canes) smoothed value along the track in the vicinity of LGB10 was $132 \mathrm{~kg} \mathrm{~m}^{-2} \mathrm{a}^{-1}(\sigma=54)$. This implies that the variability in the accumulation signal over a $30 \mathrm{~km}$ interval is mostly accounted for by noise introduced from microrelief processes. The corollary to this is that modification of the signal (at the $2 \mathrm{~km}$ sampling frequency) by mesoscale topography occurs over distances significantly greater then $30 \mathrm{~km}$.

\section{Temperature and wind regimes}

The $10 \mathrm{~m}$ firn temperature has been measured at all stations using a platinum resistance thermometer in a hole, steam drilled one year and measured the next (Fig. 4). Across the southern sector the lapse rate, $-0.8^{\circ} \mathrm{C} 100 \mathrm{~m}^{-1}\left(r^{2}=0.84\right)$, lies midway between dry and moist adiabatic values. For the western sector it has a superadiabatic value of $-1.4^{\circ} \mathrm{C}$ $100 \mathrm{~m}^{-1}\left(r^{2}=0.90\right)$, with a similar result along the eastern sector (transition stations LGB51 and LGB52 removed from the dataset) of $-1.3^{\circ} \mathrm{C} 100 \mathrm{~m}^{-1}\left(r^{2}=0.95\right)$. Mean temperatures are some $4{ }^{\circ} \mathrm{C}$ colder at equivalent clevations on the western sector as a consequence of transport of cooler air from higher elevations to the south. Overall values reflect differences in surface slopes and local surface wind regime consistent with topographical lapse rates discussed elsewhere (Allison and others, 1993).

Automatic weather stations (AWS) were deployed at all cane-farm sites apart from LGB68. Annual mean temperatures at these sites are in accord with $10 \mathrm{~m}$ firn measurements. Sastrugi orientations agree well with wind-direction data interpolated between AWS sites, apart from the southwest sector of the basin from LGB18 to LGB25 (Fig. 5), where reshuffled surfaces of large vertical extent dominate. AWS data indicate a variability of $\pm 20^{\circ}$ clockwise from the mean wind direction from autumn to spring at LGB20, maintaining production of microrelief features as opposed to continual erosion from more constant wind directions in other parts of the basin. Interpolated mean-surface winds are oriented some $20^{\circ}$ to the left of the fall line (personal communication from H. Phillips, 1996) along the eastern

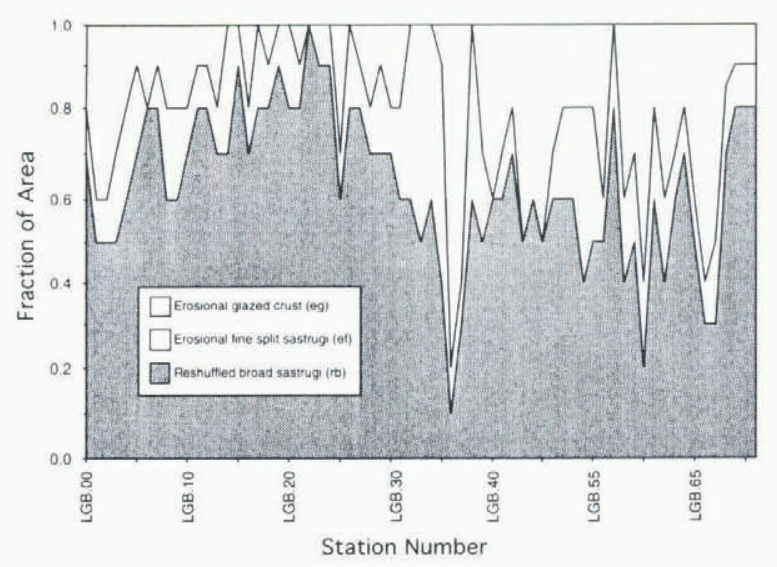

Fig. 5. Distribution of microrelief around the traverse route depicting a high predominence of reshuffled surface types, particularly for the western sector, with strong glazing evident near LGB35 along the southernmost portion of the route.

portion of the basin, increasing to $60^{\circ}$ from the southeast corner around the western sector, where down-slope katabatic winds with eastward aspect are deflected by an easterly geostrophic-wind regime.

The western side of the basin is characterised by high proportions of reshuffled drift snow forming banks, dunes and juvenile lanceolate sastrugi (Goodwin type rb, 1990),

Table 2. Cane farms. ( $n=$ number of canes, $\bar{a}=$ mean annual accumulation in $\mathrm{kg} \mathrm{m}^{-2} a^{-1}, \sigma=$ standard deviation and numbers in the bottom row are overall averages)

\begin{tabular}{|c|c|c|c|c|c|c|c|c|c|c|c|c|c|c|}
\hline & \multicolumn{2}{|c|}{$\begin{array}{l}L G B 00 \\
n=25\end{array}$} & \multicolumn{2}{|c|}{$\begin{array}{l}L G B 10 \\
n=25\end{array}$} & \multicolumn{2}{|c|}{$\begin{array}{l}L G B 20 \\
n=25\end{array}$} & \multicolumn{2}{|c|}{$\begin{array}{l}L G B 35 \\
n=25\end{array}$} & \multicolumn{2}{|c|}{$\begin{array}{l}L G B 46 \\
n=20\end{array}$} & \multicolumn{2}{|c|}{$\begin{array}{c}L G B 59 \\
n=20\end{array}$} & \multicolumn{2}{|c|}{$\begin{array}{l}L G B 68 \\
n=20\end{array}$} \\
\hline & $\bar{a}$ & $\sigma$ & $\bar{a}$ & $\sigma$ & $\bar{a}$ & $\sigma$ & $\bar{a}$ & $\sigma$ & $\bar{a}$ & $\sigma$ & $\bar{a}$ & $\sigma$ & $\bar{a}$ & $\sigma$ \\
\hline 90 & 202 & 56 & 194 & 67 & 110 & 89 & & & & & & & & \\
\hline $\begin{array}{ll}91 & 92\end{array}$ & 167 & 44 & 119 & 34 & & & & & & & & & & \\
\hline $91-93$ & & & & & 109 & 40 & 42 & 29 & & & & & & \\
\hline 93 & 109 & 61 & 51 & 33 & & & & & & & & & & \\
\hline 94 & 97 & 55 & 126 & 32 & 95 & 71 & 21 & 31 & 66 & 35 & 55 & 50 & 122 & 100 \\
\hline Mean & 149 & 52 & 122 & 40 & 106 & 56 & 37 & 29 & - & - & & & & \\
\hline
\end{tabular}


with generally $70 \%$ or more areal coverage (Fig. 6). This peaks at $100 \%$ around LGB20, where the cane farm shows consistently high standard deviations from the mean. Sastrugi heights average $0.5 \mathrm{~m}$ in this region. Strongly glazed surfaces approach $80 \%$ coverage to the east of LGB35, varying between 20 and $60 \%$ along the undulating eastern sector of the route, maximising on local topographic highs. AWS data indicate strongest winds at either end of the traverse route, where coastal slopes are greatest, and at LGB35, where the valley effect of upstream extensions of the Lambert and Mellor Glaciers again increase surface gradients in a region characterised by a higher fraction of glazed surface area.

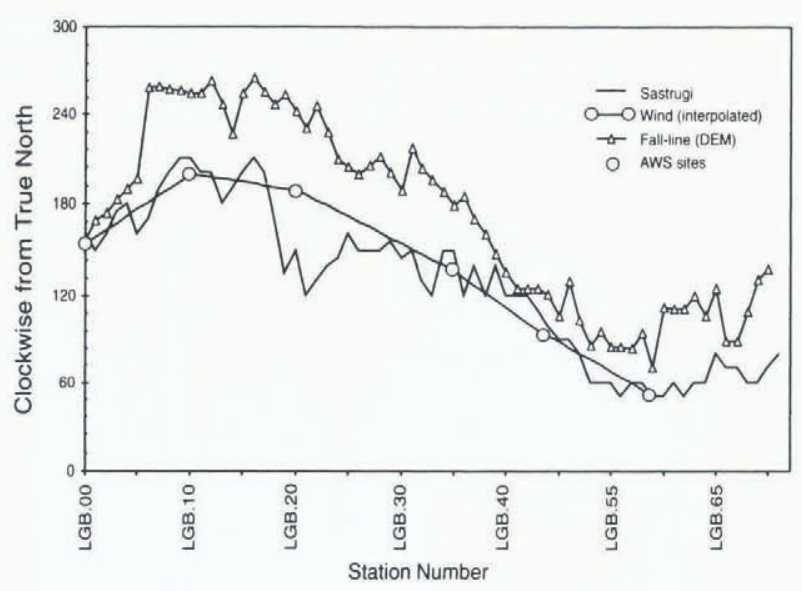

Fig. 6. Sastrugi orientation, wind interpolated from six AWS sites and fall-line calculated from a preliminary DEM (personal communication from $H$. Phillips) for the basin. Note the sharp change in fall-line direction from $L G B O 0-0.5$ down the steep coastal slope, to LGBO6 over the ridge where flow into the basin proper commences.

\section{A REVISED ACGUMULATION DISTRIBUTION FOR THE LAMBERT BASIN}

Mass-budget estimates for the Lambert basin have reported widely varying results, largely due to differences in proposed average-accumulation rates for the interior basin. McIntyre (1985) interpreted Landsat images as depicting a large ablation zone across the southern sector of the traverse route. Station LGB35 is situated on the southwestern extremity of the proposed zone where a series of heavily crevassed ice domes feature over the next $100 \mathrm{~km}$. Average winter winds (AWW) of $12 \mathrm{~m} \mathrm{~s}^{-1}$, more typical of the coastal slopes to the north, convert the surface over much of this area into wind-glazed crust $(80 \%$ coverage in places with a mixture of small erosional and reshuffled sastrugi). No bareice areas were evident in the region along the traverse route, which weaved a path north and south of the general eastwest trend to avoid heavily crevassed areas. Measurements show this zone to be a low-accumulation region, $57 \mathrm{~kg} \mathrm{~m}$ ${ }^{2} \mathrm{a}^{-1}(\sigma=69)$, associated with appreciable depth-hoar formation.

The surface mass-balance distribution for the Lambert basin (Fig. 7) has been revised using the latest compilation of accumulation data from the extensive traverse observations and spot values obtained in the interior (Kotlyakov and others, 1974). Close to the southwest perimeter of the basin reliable data on accumulation rate is available for the Pole of Relative Inaccessibility $\left(82^{\circ} 07^{\prime} \mathrm{S}, 55^{\circ} 02^{\prime} \mathrm{E}, 3718 \mathrm{~m}\right)$, Plateau Station $\left(79^{\circ} 15^{\prime} \mathrm{S}, 40^{\circ} 30^{\prime} \mathrm{E}, 3624 \mathrm{~m}\right)$ and from traverses covering this region (Koerner, 1971; Picciotto and others, 1968) using the peak in $\beta$ activity to define the 1955 annual layer. Although a number of Russian traverses have covered the southeast perimeter, their data are based upon the less reliable stratigraphic interpretation of snow pits (Kotlyakov and others, 1966). The nearest sites to this portion of the basin with reliable accumulation from $\beta$ activity are Vostok $\left(78^{\circ} 29^{\prime} \mathrm{S} 105^{\circ} 30^{\prime} \mathrm{E}, 3490 \mathrm{~m}\right)$, Komsomolskaya

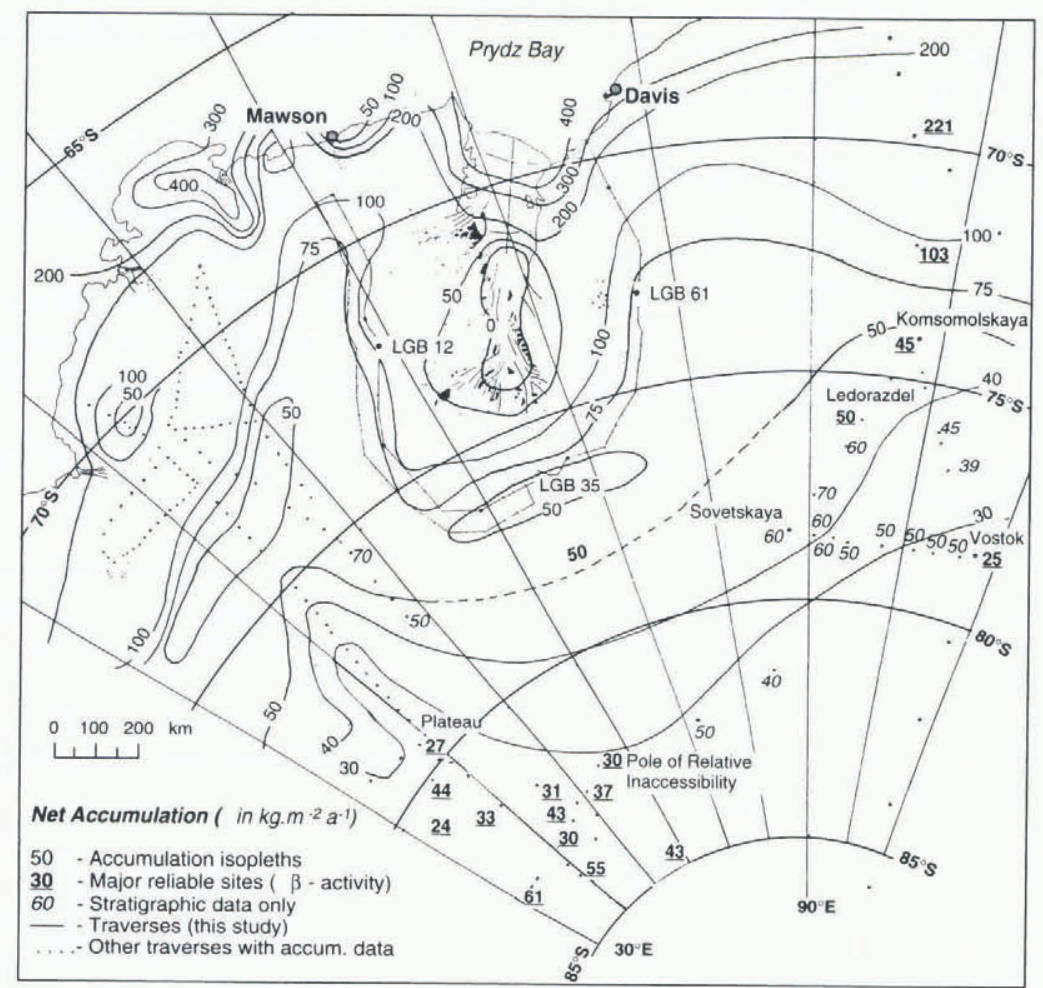

Fig. 7. New accumulation distribution for the Lambert Glacier basin. The isolated $50 \mathrm{~kg} \mathrm{~m}^{-2} \mathrm{a}^{\prime}$ isopleth at $76^{\circ}$ S is interpreted to match observed wind-glazed surfaces in the vicinity of LGB35. 
$\left(74^{\circ} 05^{\prime} \mathrm{S} \quad 97^{\circ} 29^{\prime} \mathrm{E}, \quad 3500 \mathrm{~m}\right)$ and Ledorazdel $\left(75^{\circ} 55^{\prime} \mathrm{S}\right.$ $94^{\circ} 04^{\prime} \mathrm{E}, 3730 \mathrm{~m}$ ) (see Vinogradov and Lorius, 1971). Annual accumulation rates obtained at Komsomolskaya, Vostok and on the South Pole-Dronning Maud Land traverses (1964-68) by the stratigraphic interpretation of snow pits were found to be often over-estimated when compared to that obtained from the distribution of gross $\beta$ activity (Koerner, 1971; Picciotto and others, 1971; Endo and Fujiwara, 1973). On the western side of the basin $\left(40-50^{\circ} \mathrm{E}\right)$ net accumulation has been obtained from snow stakes and stratigraphic interpretation of snow pits and shallow cores on the Japanese traverses (Endo and Fujiwara, 1973; Yamada and Watanabe, 1978; Satow and others, 1983; Takahashi and others, 1994).

At Vostok, Pole of Inaccessibility and Plateau stations, and for some of the intervening traverses, there is similar continentality and elevation. At these localities the mean accumulation rate accurately determined from $\beta$ activity was $25-30 \mathrm{~kg} \mathrm{~m}^{-2} \mathrm{a}^{-1}$. At Komsomolskaya and Ledorazdel, which are closer to the coast, accumulation rate was 45 $50 \mathrm{~kg} \mathrm{~m}^{-2} \mathrm{a}^{-1}$. The value of $60 \mathrm{~kg} \mathrm{~m}^{-2} \mathrm{a}^{-1}$ for accumulation measured at Sovetskaya (7823' S, 8732' E, $3662 \mathrm{~m}$ ) is rather high when compared to these and other neighbouring regions of similar situation. Although this value was obtained from the average of a large number of stakes over the period 1958-61, and it compares well with that obtained from snow-pit stratigraphy for the period $1952-61$, it is possible that it has been subjected to a number of undue influences. Vinogradov and Lorius (1971) attribute higher accumulation at Vostok 1 and Pionerskaya stations during the earlier studies to disturbances caused by proximity of the stake farms to station buildings (Nudelman, 1966, photograph p. 97). The value may also be influenced by the high rate of accumulation during this period, in particular during 1959. Unfortunately, the use of $\beta$ activity to identify the mean rate of accumulation is not available for Sovetskaya, and the given value is treated with caution. In any case, such a large value is regarded here as being not representative of the temporal and spatial mean applicable to the neighbouring portion of the inland Lambert basin.

No data are available for the extensive central inland basin region (beyond the $50 \mathrm{~kg} \mathrm{~m}^{-2} \mathrm{a}^{-1}$ isopleth), but by interpolation with the inland sites the areal mean is estimated to be approximately $39-54 \mathrm{~kg} \mathrm{~m}^{-2} \mathrm{a}^{-1}$.

\section{CONGLUSIONS}

Spatial accumulation rates around the Lambert Glacier basin catchment area over an elevation range $2000-3000 \mathrm{~m}$ are significantly lower than those for similar elevations in other parts of East Antarctica, for example Wilkes Land. The southern portion of the basin, around $76^{\circ} \mathrm{S}$, shows distinct continentality effects with firm wind-glazed surfaces and depth-hoar formation characteristic of a low-accumulation regime. No bare-ice areas were found in the vicinity of the traverse route along this latitude. Accumulation rates on the eastern side of the basin are lower than those at equivalent altitudes along the western sector as a result of dominant southeasterly wind fields under the combined influence of katabatic and geostrophic flows. Whilst initial stratigraphic investigations have provided largely ambiguous records, long-term average accumulation rates may still be obtainable using absolute datable horizons and charac- teristic firnification processes from shallow cores collected at various sites round the basin. A new accumulation distribution has been derived for the Lambert basin down to the $30 \mathrm{~kg} \mathrm{~m}^{-2} \mathrm{a}^{-1}$ isopleth.

\section{ACKNOWLEDGEMENTS}

The authors wish to acknowledge the support of all ANARE and Australian Antarctic Division personnel who have assisted with the field-work and preparations for LARGE, in particular R. Kiernan, who played a pivotal role in the traverse program. W. Budd, I. Goodwin and $H$. Phillips contributed useful discussion regarding modelled wind fields, surface properties and fall lines from a satellite altimeter digital-elevation model for the basin, respectively. Diagrams for the manuscript were prepared by U. Ryan.

\section{REFERENCES}

Allison, I. 1979. The mass budget of the Lambert Glacier drainage basin. Antarctica. J. Glaciol., 22 87), 223235.

Allison, I., G. Wendler and U. Radok. 1993. Climatology of the East Antarctic ice sheet $100^{\circ} \mathrm{E}$ to $\left.140^{\circ} \mathrm{E}\right)$ derived from automatic weather stations. J. Geophss. Res., 98 D5). 88158823.

Budd, W. F., P. A. Reid and L. J. Minty. 1995. Antaretic moisture flux and net accumulation from global atmospheric analyses. Amn. Glaciol., 21, 149 156.

Endo, Y. and K. Fujiwara. 1973. Characteristics of the snow cover in East Antarctica along the route of the JARE South Pole traverse and factors controlling such characteristics. J.ARE Sci. Rep., Ser, C. 7, $1-27$.

Giovinetto, M. B. and C. Bull. 1987. Summary and analysis of surface mass balance compilations for Antarctica, 1960-1985. Byrd Polar Research Center Reportl.

Goodwin, I. D. 1990. Snow accumulation and surface topography in the katabatic zone of eastern Wilkes Land, Antarctica. Antarct. Sci., 2 (3). 235242.

Goodwin, I. D., M. Higham, I. Allison and R. Jaiwen. 1994. Accumulation variation in castern Kemp Land, Antarctica. Ann. Glaciol., 20, 202- 206.

Koerner, R. M. 1971. A stratigraphic method of determining the snow accumulation rate at Plateau Station, Antarctica, and application to the South Pole Queen Maud Land traverse 2, 1965 1966. In Crary, A.P., ed. Antarctic snow and ice sludies II. Washington, DC, American Geophysical Union, 225-238. (Antarctic Research Series 16.

Kotlyakov. V. M., G. Ye. Lazarev and M. M. Lvubarets. 1966. New data on the snow accumulation regime in the interior of East Antarctica. Sot. Antarct. Exped. Inf. Bull., 2 6), $116-123$.

Kotlyakov, V. M., N. N. Barkov, I. A. Loseva and B. N. Petrov. 1974. Novaya Karta pitaniva lednikovogo pokrova Antarktidy [New map of the accumulation on the Antarctic ice sheet]. Mater. Glyatsiol. Issled. 24, 248255.

McIntyre, N. F. 1985. A re-assessment of the mass balance of the Lambert Glacier drainage basin, Antarctica. f. Glaciol., 31 (107),34-38.

Nudelman, A.V. 1966. Soviel Antarctic expeditions 195.5-1959. Jerusalem, Isracl Program for Scientific Translations.

Picciotto, E., R. Cameron, G. Crozaz, S. Deutsch and S. Wilgain. 1968. Determination of the rate of snow accumulation at the Pole of Relative Inaccessibility, castern Antarctica: a comparison of glaciological and isotopic methods. F. Glaciol., 7 (50), 273-287.

Picciotto, E., G. Crozaz and W. de Breuck. 1971. Accumulation on the South Pole- Qucen Maud Land traverse. 1964-1968. In Crary. A. P.. ed. Antartic snow and ice studies II. Washington, DC, American Geophysical Union. 257 -315. Antarctic Research Series 16.

Satow, K., H. Nishimura and J. Inoue. 1983. Glaciological data collected by the Japanese Antarctic Research Expedition in 1981. J.ARE Data Rep. 82. (Glaciology 9.).

Takahashi, S., Y. Ageta, Y. Fujii and O. Watanabe. 1994. Surface mass balance in east Dronning Maud Land, Antarctica, observed by Japanese Antaretic Research Expeditions. Ann. Glaciol., 20, 242-248.

Vinogradov, O. N. and C. Lorius. 1971. Evaluation of the results of snow accumulation measurements along the Mirny Observatory-Vostok Station profile on the basis of Soviet-French investigations in 1964-69. Sot. Antarct. Exped. Inf. Bull., 8 5), 237-240.

Yamada, T. and O. Watanabe. 1978. Estimation of mass input in the Shirase and the Soya drainage basins in Mizuho Plateau. National Institute of Polar Research. Memoirs 7, Special Issue, $182-197$. 